\title{
DIELECTRIC CONSTANT OBTAINED FROM TDR AND VOLUMETRIC MOISTURE OF SOILS IN SOUTHERN BRAZIL $^{(1)}$
}

\author{
Douglas Rodrigo Kaiser ${ }^{(2)}$, Dalvan José Reinert ${ }^{(3)}$, José Miguel \\ Reichert $^{(3)}$ \& Jean Paollo Gomes Minella ${ }^{(4)}$
}

\begin{abstract}
SUMMARY
Soil moisture is the property which most greatly influences the soil dielectric constant, which is also influenced by soil mineralogy. The aim of this study was to determine mathematical models for soil moisture and the dielectric constant (Ka) for a Hapludalf, two clayey Hapludox and a very clayey Hapludox and test the reliability of universal models, such as those proposed by Topp and Ledieu and their co-workers in the 80 's, and specific models to estimate soil moisture with a TDR. Soil samples were collected from the 0 to $0.30 \mathrm{~m}$ layer, sieved through a mesh of $0.002 \mathrm{~m}$ diameter and packed in PVC cylinders with a $0.1 \mathrm{~m}$ diameter and $0.3 \mathrm{~m}$ height. Seven samples of each soil class were saturated by capillarity and a probe composed of two rods was inserted in each one of them. Moisture readings began with the saturated soil and concluded when the soil was near permanent wilting point. In each step, the samples were weighed on a precision scale to calculate volumetric moisture. Linear and polynomial models were adjusted for each soil class and for all soils together between soil moisture and the dielectric constant. Accuracy of the models was evaluated by the coefficient of determination, the standard error of estimate and the 1:1 line. The models proposed by Topp and Ledieu and their co-workers were not adequate for estimating the moisture in the soil classes studied. The adjusted linear and polynomial models for the entire set of data of the four soil classes did not have sufficient accuracy for estimating soil moisture. The greater the soil clay and Fe oxide content, the greater the dielectric constant of the medium for a given volumetric moisture. The specific models, $\theta=$ $0.40283-0.04231 \mathrm{Ka}+0.00194 \mathrm{Ka}^{2}-0.000022 \mathrm{Ka}^{3}$ (Hapludox) $\theta=0.01971+0.02902 \mathrm{Ka}$
\end{abstract}

\footnotetext{
(1) Received for publication in Juny 2009 and accepted in March 2010.

(2) Doctoral candidate in Soil Science. UFSM. CAPES Scholarship holder. E-mail: douglasrodrigokaiser@gmail.com

(3) Full Professor of the Soils Department, Rural Sciences Center, Universidade Federal de Santa Maria (Federal University of Santa Maria) - UFSM. University Campus. CEP 97105-900. Santa Maria (RS) Brazil. E-mails: dalvan@ccr.ufsm.br; reichert@smail.ufsm.br

(4) Adjunct Professor of the Soils Department-UFSM. E-mail: jminella@smail.ufsm.br
} 


\begin{abstract}
- $0.00086 \mathrm{Ka}^{2}+0.000012 \mathrm{Ka}^{3}$ (Hapludox $\left.-\mathrm{PF}\right), \theta=0.01692-0.00507 \mathrm{Ka}$ (Hapludalf) and $\theta=0.08471+0.01145 \mathrm{Ka}($ Hapludox-CA), show greater accuracy and reliability for estimating soil moisture in the soil classes studied.
\end{abstract}

Index terms: mathematical models, soil moisture, TDR, calibration.

\author{
RESUMO: CONSTANTE DIELÉTRICA OBTIDA COM TDR E A UMIDADE \\ VOLUMÉTRICA DE SOLOS DO SUL DO BRASIL
}

\begin{abstract}
A umidade do solo é a propriedade com maior influência sobre a constante dielétrica do meio, sendo também influenciada pela mineralogia do solo. O objetivo deste estudo foi estabelecer modelos matemáticos entre a umidade e a constante dielétrica (Ka) para um Argissolo, dois Latossolos e um Nitossolo e compará-los com os modelos universais propostos na literatura, como os de Topp e Ledieu e seus colaboradores nos anos 80, e modelos específicos para estimar a umidade com o uso de TDR. Amostras de solo foram coletadas na camada de o a 0,30 m, peneiradas em malha com diâmetro de 0,002 $\mathrm{m}$ e acondicionadas em cilindros de $P V C$ de 0,1 m de diâmetro e 0,3 $\mathrm{m}$ de altura. Sete amostras de cada classe de solo foram saturadas por ascensão capilar e, em cada uma delas, inseriu-se uma sonda composta de duas hastes. As leituras de umidade iniciaram-se com o solo saturado e terminaram quando a umidade estava próxima ao ponto de murcha permanente. Em cada etapa, as amostras foram pesadas em balança de precisão, para calcular a umidade volumétrica. Foram ajustados modelos lineares e polinomiais, para cada classe de solo e para todo o conjunto, entre a umidade e a constante dielétrica. A precisão dos modelos foi avaliada pelo coeficiente de determinação, pelo erro-padrão da estimativa e pela a linha 1:1. Os modelos propostos por Topp e Ledieu e seus colaboradores não se mostraram adequados para estimar a umidade das classes de solos estudadas. Os modelos linear e polinomial ajustados para todo o conjunto de dados das quatro classes de solo não apresentam precisão suficiente para estimar a umidade dos solos. A medida que aumenta o teor de argila e de óxidos de ferro do solo, maior é a constante dielétrica do meio para a mesma umidade volumétrica. Os modelos específicos, $\theta=$ 0,40283 - 0,04231 Ka +0,00194 Ka $\mathrm{K}^{2}-0,000022 \mathrm{Ka}^{3}$ (Nitossolo), $\theta=0,01971+0,02902 \mathrm{Ka}$ - 0,00086 Ka $\mathrm{K}^{2}+0,000012 \mathrm{Ka}^{3}$ (Latossolo-PF), $\theta=0,01692-0,00507 \mathrm{Ka}$ (Argissolo) e $\theta=$ $0,08471+0,01145 \mathrm{Ka}$ (Latossolo-CA), apresentam maior precisão e confiabilidade para estimativa da umidade das classes de solos estudadas.
\end{abstract}

Termos de indexação: modelos matemáticos, água no solo, TDR, calibração.

\section{INTRODUCTION}

Soil moisture is a property that affects aeration, resistance and susceptibility to compaction, demanding equipment that allows spatial and temporal monitoring. Among the techniques used in the evaluation of soil moisture, Time Domain Reflectometry (TDR) has been amply indicated as a non-destructive method with great potential for the evaluation of soil moisture in real time. With the automatization of TDR, connecting it to multiplexers and data storage devices (Baker \& Allmaras, 1990), continuous monitoring of soil moisture at various points is possible, allowing studies of water and solute movement (Topp et al., 1982) and plant water availability (Jackson \& Wallace, 1999).

This technique was initially introduced for measurement of dielectric properties of liquids and, as of 1980, it began to be considered as a promising technique in soil science. The technique is based on a time estimate $(t)$ of the propagation of electromagnetic waves with frequencies from $1 \mathrm{MHz}$ to $1 \mathrm{GHz}$ and a speed of $30 \mathrm{~cm} \mathrm{~ns}^{-1}(c)$, in a metallic guide of known length $(L)$ inserted in the soil, to estimate the apparent dielectric constant of the soil $(K a)$, through the equation:

$$
K a=\left(\frac{c t}{2 L}\right)^{2}
$$

Water is the component that has the greatest influence on the apparent dielectric constant of the soil, for it has a relative dielectric constant (81) much greater than the mineral and organic soil particles (2-7), which makes it possible to estimate the volumetric moisture of a given soil type in terms of its dielectric constant (Topp et al., 1980). The greater the water content in the medium, the greater the time necessary for displacement of the electric pulse in the metallic rods inserted in the medium and the greater its apparent dielectric constant. 
Empirical models that relate soil volumetric moisture with the soil dielectric constant are practical and useful for establishing calibration curves of TDR and have been investigated by different authors (Otto \& Alcaide, 2001; Tommaselli \& Bacchi, 2001; Teixeira et al., 2003; Coelho et al., 2006). Although the models proposed by Topp et al. (1980) and Ledieu et al. (1986) estimate soil moisture in a satisfactory manner, the adjusted models have their applicability limited to local conditions in terms of differences that exist in electrical conductivity, clay and quartz content (Tommaselli \& Bacchi, 2001) and soil organic matter (Pumpanem \& Iivesniemi, 2005).

The use of a single general empirical model adjusted for different soil types may compromise accuracy of soil moisture determinations when applied to each soil individually (Tommaselli \& Bacchi, 2001; Teixeira et al., 2003). Specific models originate from calibration curves for each soil condition and type (Coelho et al., 2006).

Various researchers (Souza \& Matsura, 2002; Souza \& Matsura, 2004; Collares et al., 2006; Pereira et al., 2006; Collares et al., 2006; Collares et al., 2008; Reichert et al., 2009) have used TDR for monitoring soil moisture and water availability for plants under conditions in Brazil, but few studies deal with the evaluation of calibration equations of the device for Brazilian soils.

Therefore the aim of this study was to determine and evaluate calibration equations between soil moisture and the dielectric constant for some soils that are agriculturally important in southern Brazil using TDR.

\section{MATERIAL AND METHODS}

Calibration of the TDR-100 equipment was undertaken in the Soil Physics Laboratory at the Federal University of Santa Maria (Universidade Federal de Santa Maria - UFSM). Four soils were used in this study: a Hapludox with a clay texture, from Passo Fundo -RS (Latossolo Vermelho distrófico típico), a Hapludalf with a sandy texture, from Santa
Maria-RS (Argissolo Vermelho distrófico arênico), a Hapludox with a very clayey texture from Cruz Alta RS (Latossolo Vermelho distroférrico típico) and a Hapludox with a very clayey texture, from Campos Novos-SC (Nitossolo Vermelho). Granulometric analysis was determined by the pipette method, while mineralogical composition was obtained from Brasil (1973), for the soil of Rio Grande do Sul, and from Embrapa (2004), for the soil of Santa Catarina (Table 1).

The mineralogical composition of the sand fraction of the soils is dependent on the parent material and the degree of weathering reached (BRASIL, 1973). The Hapludox, from Passo Fundo (RS), presents a sand fraction composed of $99 \%$ hyaline quartz, $1 \%$ magnetite and some traces of Fe oxides, garnet and debris. The Hapludox from Cruz Alta (RS) presents $90 \%$ magnetite, $5 \%$ hyaline quartz and $5 \%$ debris in the sand fraction. The Hapludalf from Santa Maria (RS) presents $100 \%$ clear vitreous quartz in the sand fraction and some traces of feldspars, biotite and ferruginous concretions. Together, these soils represent $12.6 \%$ of the territory of Rio Grande do Sul (BRASIL, 1973). The Hapludox from Campos Novos - SC is found in $14.36 \%$ of the territory of Santa Catarina and presents $86 \%$ quartz and $14 \%$ clayey iron nodules and traces of chlorite, magnetite, mica, coal and debris (Embrapa, 2004).

Disturbed samples were collected from the 0 to $0.30 \mathrm{~m}$ layer and dried in open air and sieved through a $0.002 \mathrm{~m}$ diameter mesh. For the measurements with the TDR-100, the samples were prepared by successively packing small quantities of soils $(0.02 \mathrm{~m})$ in PVC columns with a $0.1 \mathrm{~m}$ diameter and $0.3 \mathrm{~m}$ height (Figure 1a).

Mean soil density in the columns was $1.48 \mathrm{Mg} \mathrm{m}^{-3}$ for the Hapludalf, $1.27 \mathrm{Mg} \mathrm{m}^{-3}$ for the Hapludox (Campos Novos -SC), and $1.14 \mathrm{Mg} \mathrm{m}^{-3}$ for the Hapludox (Passo Fundo, Cruz Alta - RS). For each soil, seven PVC columns were used. The samples were slowly saturated by capillarity and, after saturation, a probe with two rods was inserted in each one. These probes were connected to a multiplexer and to the TDR100 , with readings being made automatically every 30 min.

Table 1. Granulometric and mineralogical composition of the studied soils (Taken from Brasil, 1973 and Embrapa, 2004)

\begin{tabular}{|c|c|c|c|c|c|c|c|c|}
\hline Soil & Clay & Silt & Sand & $\mathrm{SiO}_{2}$ & $\mathrm{Al}_{2} \mathrm{O}_{3}$ & $\mathrm{Fe}_{2} \mathrm{O}_{2}$ & $\mathrm{TiO}_{2}$ & MnO \\
\hline & \multicolumn{8}{|c|}{$-\mathrm{g} \mathrm{kg}^{-1}$} \\
\hline Hapludalf & 90 & 297 & 613 & 59 & 135 & 17 & 2.7 & - \\
\hline Hapludox (Passo Fundo-RS) & 549 & 266 & 185 & 154 & 123 & 85 & 13 & - \\
\hline Hapludox (Cruz Alta-RS) & 619 & 179 & 202 & 245 & 211 & 246 & 45 & 2.9 \\
\hline Hapludox (Campos Novos-SC) & 705 & 271 & 24 & 222 & 202 & 217 & 38.7 & 3.6 \\
\hline
\end{tabular}




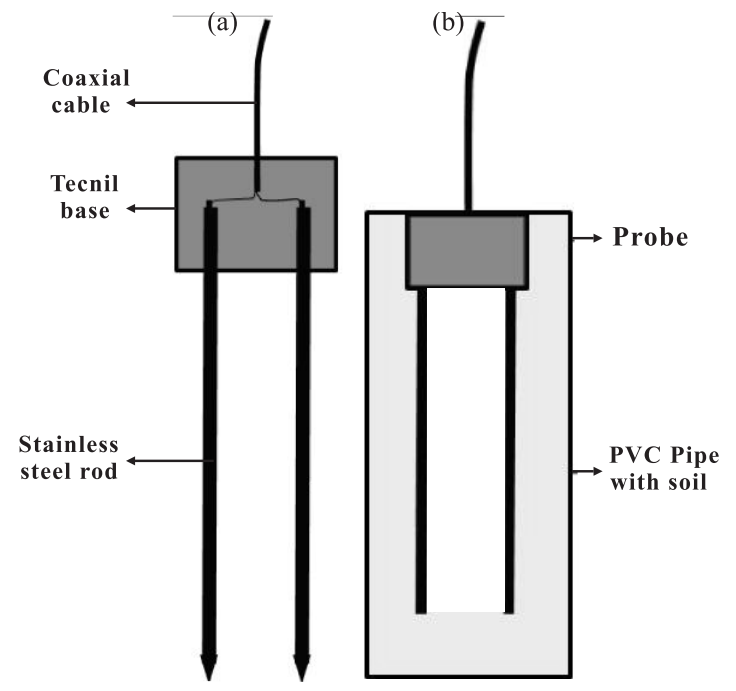

Figure 1. TDR probe and installation setup used. (a) details and (b) probe inserted into a soil column.

The probes were constructed in the soil physics laboratory at UFSM, being composed of two stainless steel rods of $0.005 \mathrm{~m}$ diameter and $0.23 \mathrm{~m}$ length and spaced at $0.045 \mathrm{~m}$. The probe head was constructed of technyl which maintained the rods parallel, and connected to a $50 \mathrm{Ohm}$ coaxial cable (Figure $1 \mathrm{~b}$ ). The extremity of the coaxial cable had a BNC connector, which connected with the TDR device.

The soil moisture readings began with the saturated soil and were concluded when the soil reached a moisture level near the permanent wilting point. For the Hapludox the permanent wilting point was reached 40 days after saturation, whereas for the Hapludalf it took 38 days after saturation of the samples. Initially, moisture variation was obtained placing the samples in a tension table at 0.10 and $0.60 \mathrm{~m}$ of suction. After equilibrium, the samples were weighed on a precision scale and readings were made with the TDR-100 equipment. Afterwards, in variable time intervals, the samples were placed in a laboratory drying oven at $60^{\circ} \mathrm{C}$. After reaching the desired moisture level, the samples were cooled and soil moisture readings were made with the TDR device. Finally, the samples were removed from the PVC cylinders and placed in aluminum cans and dried in a laboratory oven at $105{ }^{\circ} \mathrm{C}$ to determine the soil dry weight. These values were used to calculate the gravimetric moisture and soil bulk density. The volumetric moisture was estimated by multiplying the soil bulk density by the gravimetric moisture.

Linear and polynomial models were adjusted to the Ka obtained with the TDR and the volumetric soil moisture for each soil class and also for the entire set of data. The data obtained were compared to the equations of Topp et al. (1980) and of Ledieu et al. (1986), [2] and [3] respectively, which are considered universal and are used in a great deal of commercial equipment of the TDR type.

$$
\begin{gathered}
\theta=0.0000043 K a^{3}-0.00055 K a^{2}+0.029 K a-0.053 \\
\theta=0.1138 \sqrt{ } K a-0.1758
\end{gathered}
$$

Accuracy of the models was evaluated by the coefficient of determination $\left(R^{2}\right)$, by the 1:1 line between the observed data and data estimated by the models, and by the standard error of estimate (Sxy). The Sxy is a measure of dispersion between the values observed and estimated by regression, with the one having the lowest value being desired (Schneider et al., 2009).

\section{RESULT AND DISCUSSION}

The result of the adjustments of the equations proposed by Topp et al. (1980) and Ledieu et al. (1986) considering the soils studied is presented in figure 2 . Both equations overestimated the values of volumetric moisture for the Hapludox (Campos Novos - SC) and there was an underestimation of lower moisture values in the Hapludox (Passo Fundo - RS). Thus, these equations, which are considered universal and are used in the algorithms of the TDR devices, may not be generalized for all soil classes, especiallly for tropical soils that present a wide variation in their mineralogical composition (Tomaselli \& Bacchi, 2001).

Adjustment of the linear and polynomial models to the entire set of data did not lead to improvements in the soil moisture estimates from the dielectric constant measured by the TDR (Figure 3). The cubic polynomial model had the best adjustment $\left(R^{2}=0.80\right)$, but overestimated moisture for the soil classes with low Ka and underestimated it for the soil classes with high Ka. The linear model presents less efficiency in the moisture estimate for the entire set of data, which is shown by the lower coefficient of determination

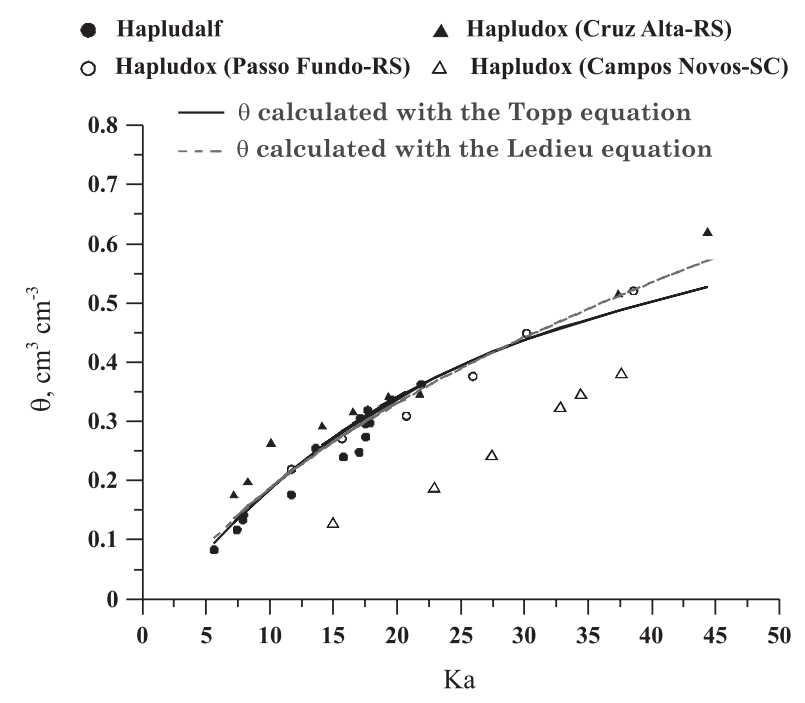

Figure 2. Relation between the dielectric constant (Ka) measured with the TDR-100 and the volumetric soil moisture $(\theta)$ determined and calculated by the Topp and Ledieu equation. 


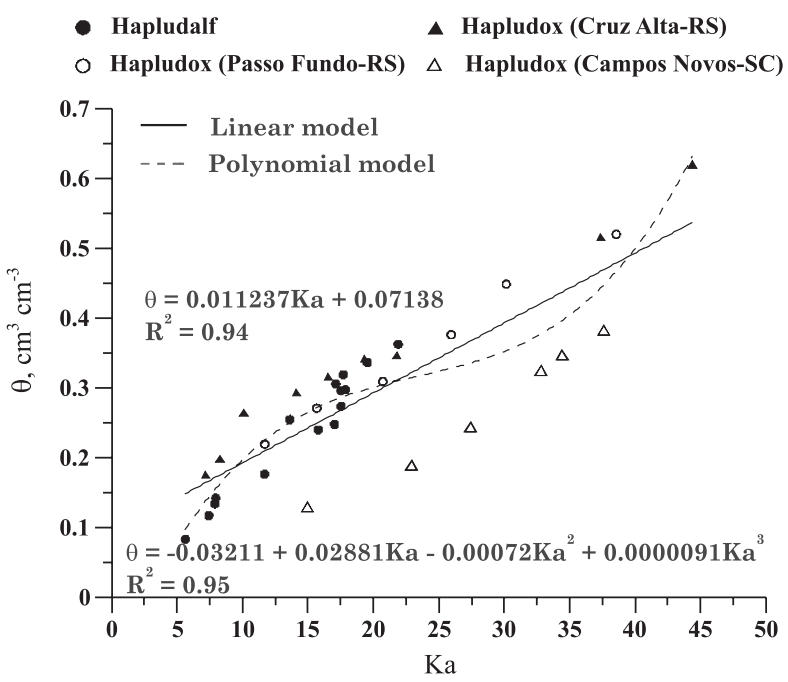

Figure 3. Relation between the dielectric constant (Ka) measured with the TDR-100 and the volumetric soil moisture $(\theta)$ determined and calculated by the linear and polynomial models.

$\left(\mathrm{R}^{2}=0.74\right)$. This dispersion of points makes the use of a single model difficult for estimating moisture in different soils, and shows the need for generating specific models for soil classes more homogeneous in terms of pedogenetic and mineralogical properties.

Each soil class has a specific relation between the moisture and its dielectric constant, which is demonstrated by the difference in the linear and angular coefficients of the adjusted models (Figure 4). The Hapludalf, since it is sandy, has little influence of the clay minerals on the speed of propagation of the electromagnetic waves and, thus, a small variation in its Ka already indicates increase in soil moisture, with this being confirmed by the angular coefficient of the linear model for this soil (Figure 4, Table 2). The Hapludox from Campos Novos (SC), being highly weathered, presents a large quantity of iron oxides in its composition (Table 1). The highly weathered Hapludox presents a greater quantity of iron oxides and greater specific surface area (Brasil, 1973), which have a greater effect on the speed of propagation of electromagnetic waves (Tomaselli \& Bacchi, 2001) and, thus, the water content in the soil is less for the same value of $\mathrm{Ka}$ observed in the other soil classes. For soils from a temperate climate region, Topp et al. (1980) did not find significant influence of soil class, soil bulk density, concentration of salts and temperature on the dielectric constant of the soil, with the observed error in the soil moisture estimate by Ka of only $1.3 \%$. Nevertheless, for tropical soils this condition is not true (Tomaselli \& Bacchi, 2001).

The polynomial model had better adjustments for the Hapludox from Campos Novos (SC) and Passo Fundo (PF) (Figures 5 and 6), with a greater coefficient of determination and lower standard error of estimate (Sxy) (Tables 2 and 3), while the linear model had a better adjustment for the Hapludalf and the Hapludox from Cruz Alta (RS) (Figure 5 and 6). Nevertheless, both the adjusted models (linear and polynomial) had better adjustment and less error in the estimate of volumetric soil moisture than the general models proposed for all the soils studied. In addition, the specific models also presented better efficiency than the models proposed by Topp et al. (1980) and Ledieu et al. (1986), which is indicated by the greater coefficient of determination of the model $\left(\mathrm{R}^{2}\right)$ and less

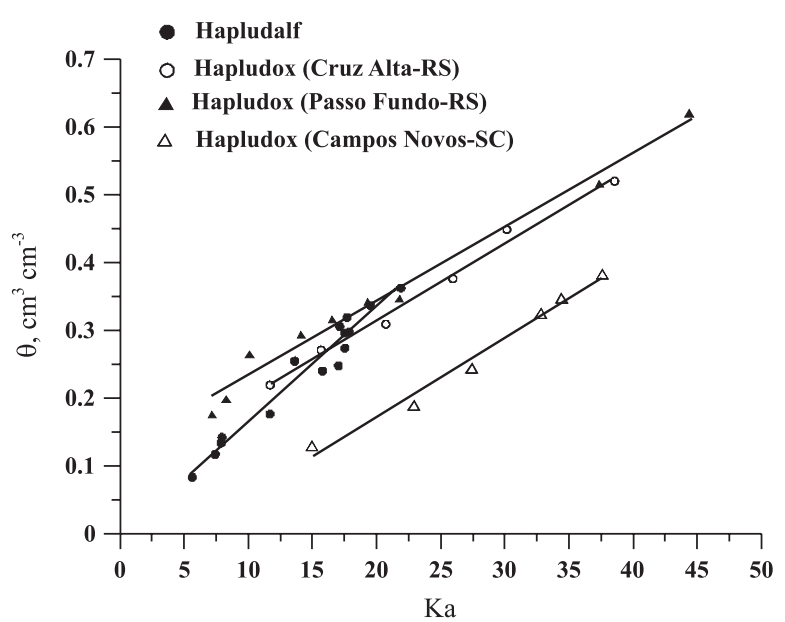

Figure 4. Relation between the dielectric constant (Ka) measured with the TDR-100 and the volumetric soil moisture $(\theta)$ determined and calculated by the linear and polynomial models.

Table 2. Analysis of variance for the linear models

\begin{tabular}{|c|c|c|c|c|c|c|}
\hline Soil & $\begin{array}{l}\text { Estimate of the } \\
\text { parameter - Ka }\end{array}$ & Linear coefficient & $\operatorname{Pr}>\mathbf{F}$ & $\mathbf{R}^{2}$ & Sxy (1) & $\begin{array}{c}\operatorname{Pr}>t \\
\text { Ka }\end{array}$ \\
\hline All soils & 0.01007 & 0.09186 & $<0.0001$ & 0.74 & 0.061 & $<0.0001$ \\
\hline Hapludalf & 0.01692 & -0.00507 & $<0.0001$ & 0.96 & 0.019 & $<0.0001$ \\
\hline Hapludox (Passo Fundo-RS) & 0.01145 & 0.08471 & $<0.0001$ & 0.99 & 0.013 & $<0.0001$ \\
\hline Hapludox (Cruz Alta-RS) & 0.01970 & 0.12320 & $<0.0001$ & 0.98 & 0.020 & $<0.0001$ \\
\hline Hapludox (Campos Novos-SC) & 0.01163 & -0.06021 & $<0.0001$ & 0.98 & 0.015 & $<0.0001$ \\
\hline
\end{tabular}

(1) Standard error of estimate. 
dispersion of the points on the 1:1 line (Tables 2 and 3, Figures 7, 8, 9 and 10).

The results of analysis of variation for the linear and polynomial models are in tables 2 and 3 . All the
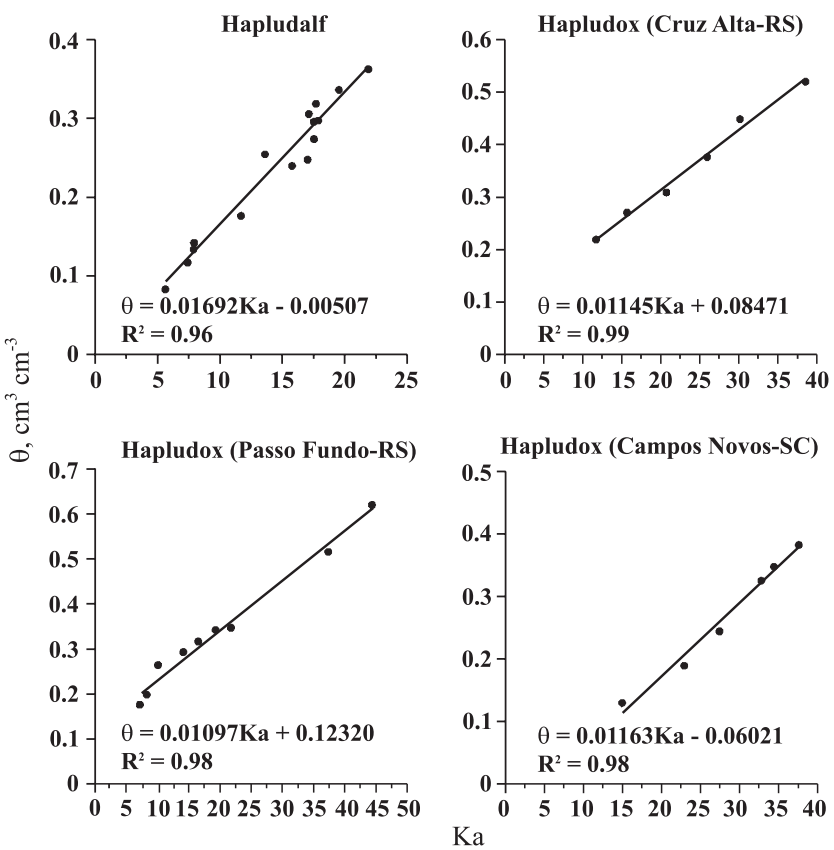
dielectric constant obtained with the TDR and the volumetric soil moisture.

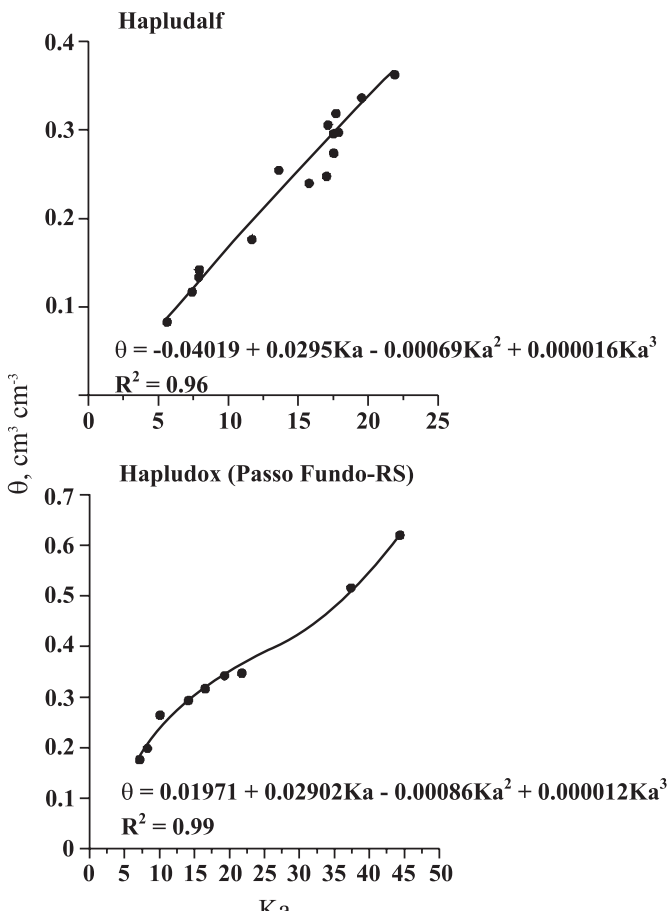

Figure 5. Linear model adjusted between the

models presented are significant with a confidence level greater than $99 \%$ (Prob > F). The cubic coefficients for the polynomial model determined for the Hapludalf and for the Hapludox from Cruz Alta (RS) are not significant, as indicated by the t test (Table 3). The linear coefficient of the models is highly significant in the models evaluated. Nevertheless, the low coefficient of determination $\left(\mathrm{R}^{2}\right)$ and the high standard error of estimate (Sxy) indicate that the general models have low efficiency in estimating soil moisture.

The 1:1 graphical relation indicate that the linear model presented the points near the 1:1 line, showing less dispersion and better accuracy in the estimation of moisture (Figure 7), while the polynomial model overestimated the higher moisture points for the Hapludox (Figure 8).

The model proposed by Topp et al. (1980) overestimated moisture content of the Hapludox from Campos Novos (SC) throughout the range observed, and underestimated lower moisture contents and overestimated the higher moisture values of the Hapludox from Passo Fundo (RS) (Figure 9). The same behavior was observed when the model from Ledieu et al. (1986) was tested for these soils (Figure 10). Therefore, to obtain more precise information regarding soil moisture with the use of the TDR technique, specific calibration curves for each soil class are necessary, principally the highly weathered soils that have a greater quantity of iron oxides in their composition.
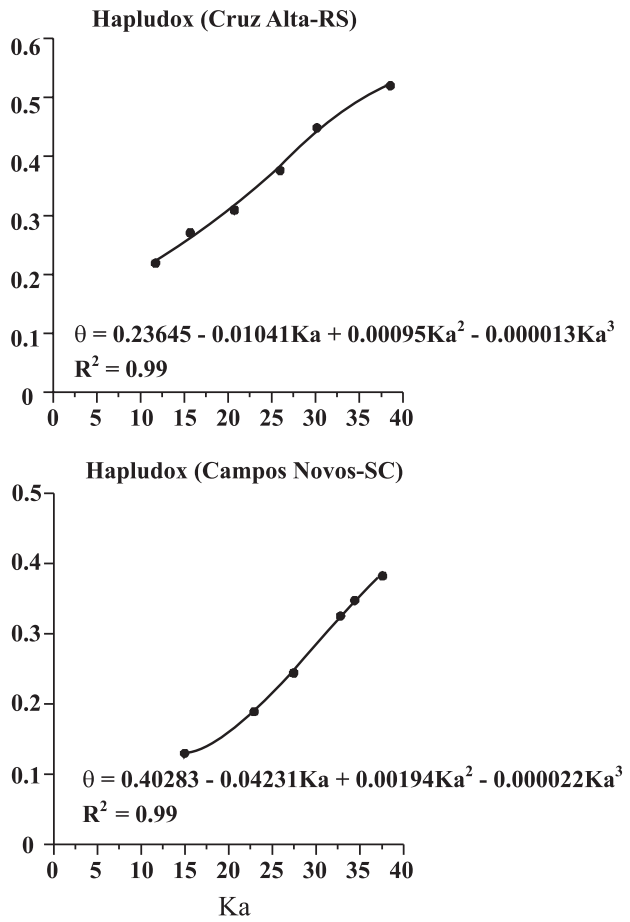

Figure 6. Polynomial model adjusted between the dielectric constant obtained with the TDR and the volumetric soil moisture. 

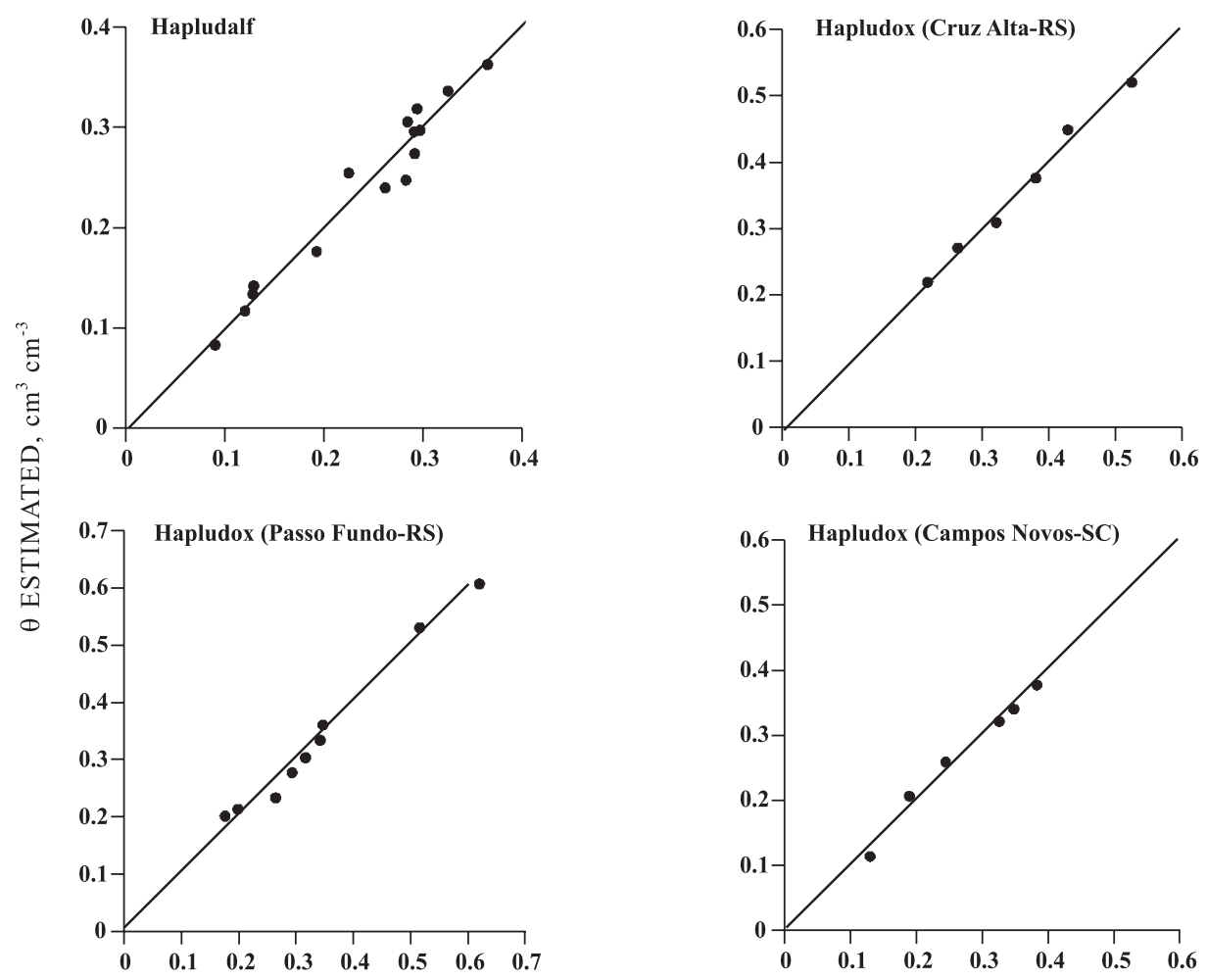

$\theta$ OBSERVED, $\mathrm{cm}^{3} \mathrm{~cm}^{-3}$

Figure 7. Relationship (1:1 graphic) between the volumetric soil moisture observed and that estimated with the linear model.
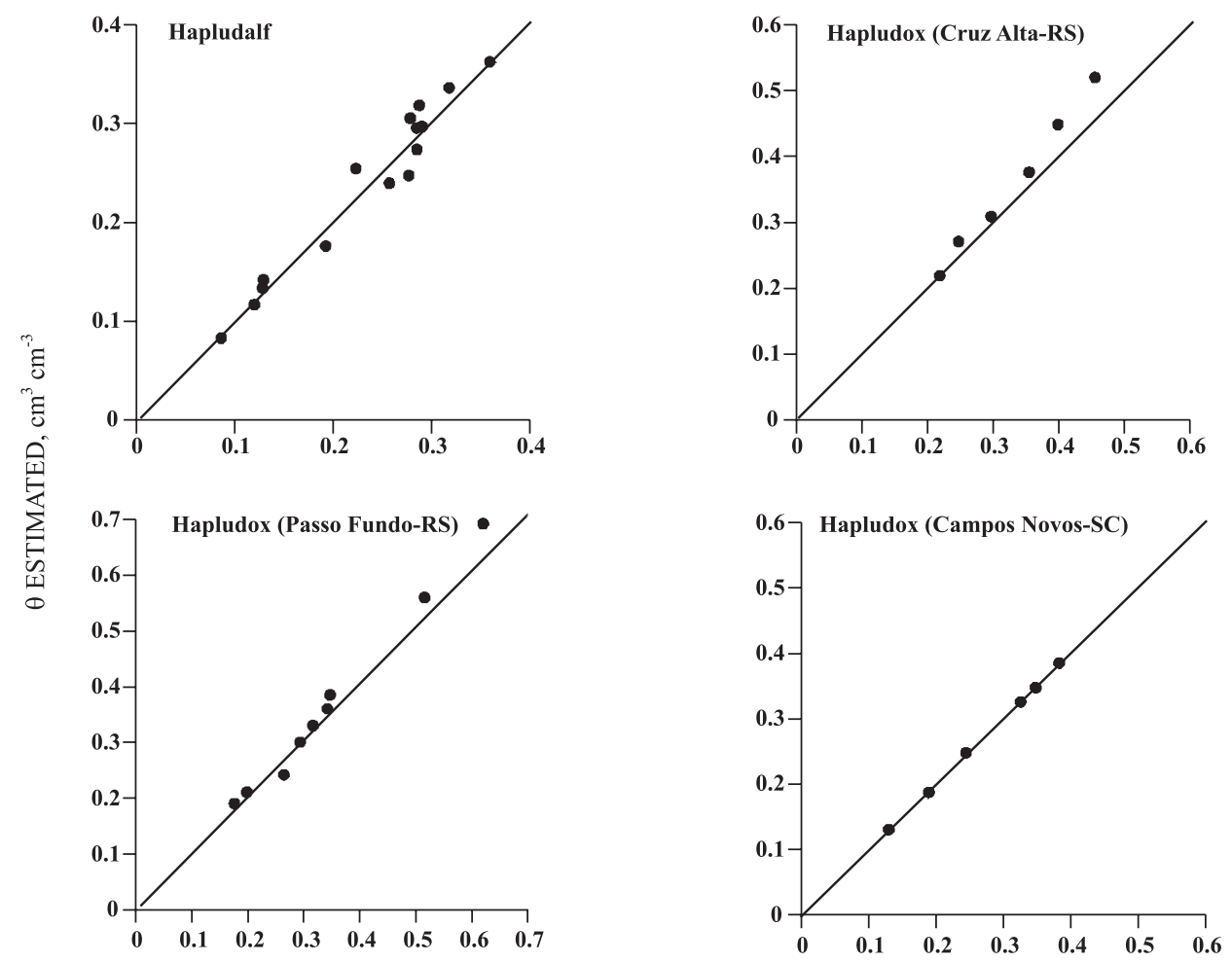

$\theta$ OBSERVED, $\mathrm{cm}^{3} \mathrm{~cm}^{-3}$

Figure 8. Relationship (1:1 graphic) between the volumetric soil moisture observed and that estimated with the polynomial model. 


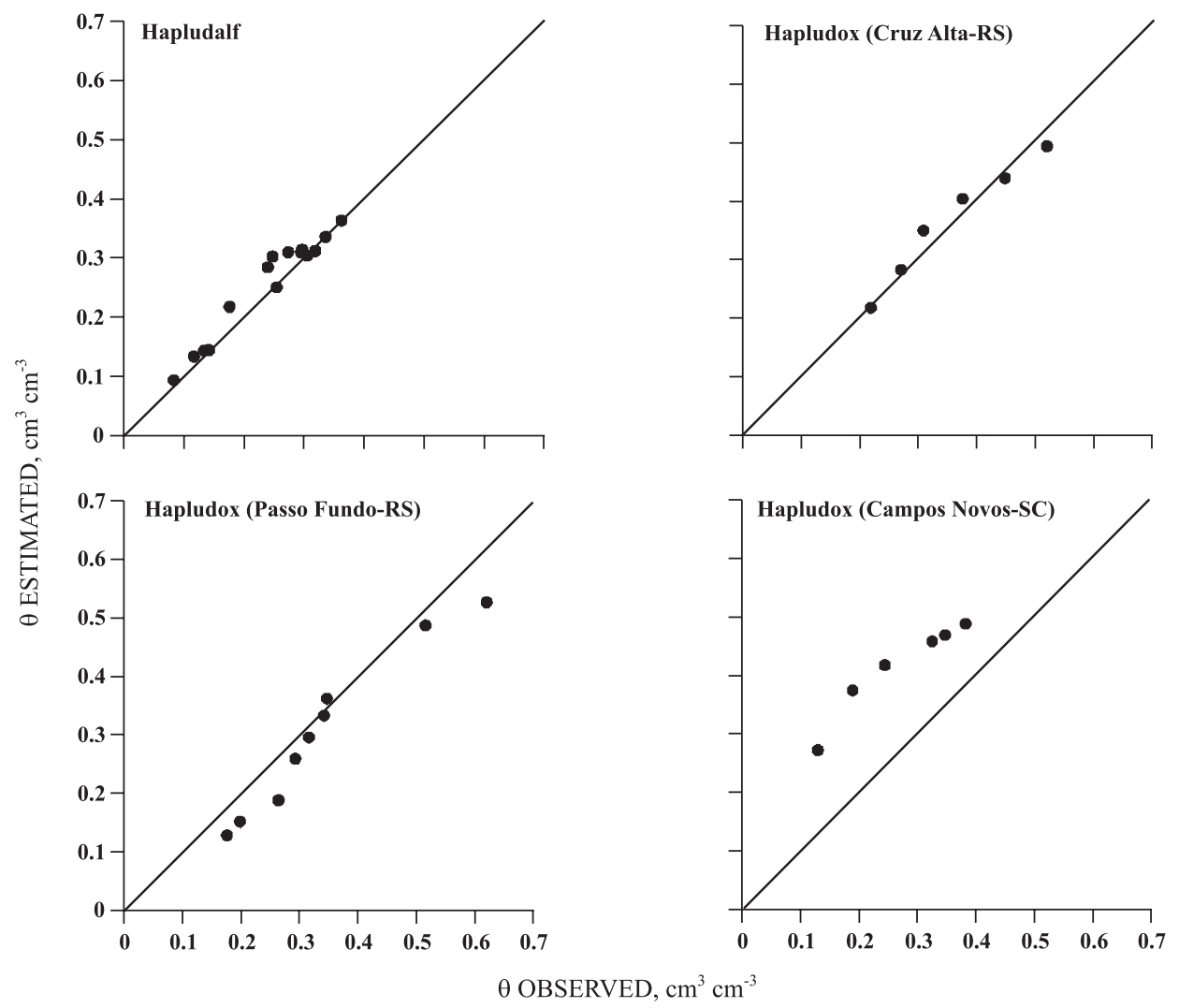

Figure 9. Relationship (1:1 graphic) between the volumetric soil moisture observed and that estimated with the model proposed by Topp et al. (1980).
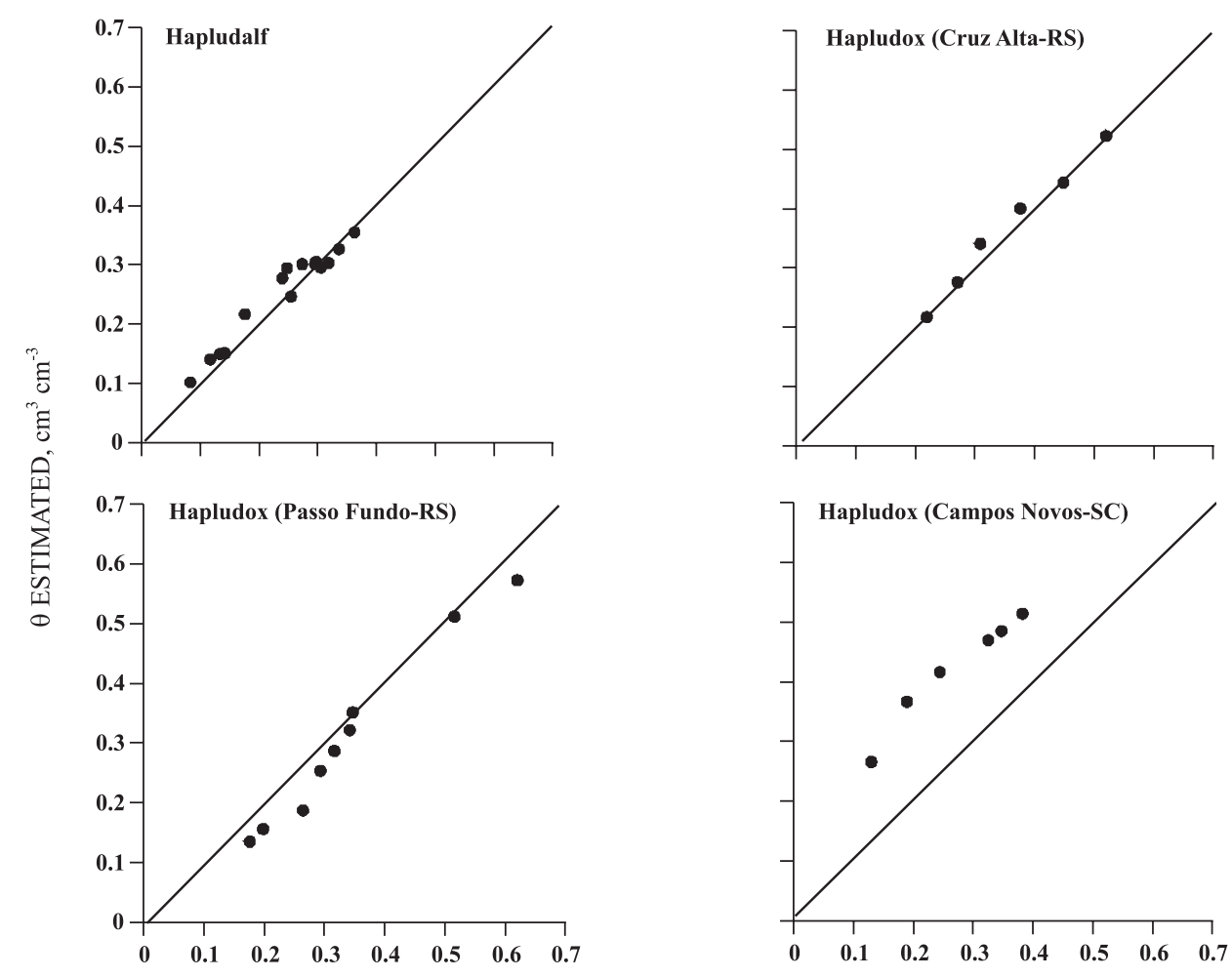

$\theta$ OBSERVED, $\mathrm{cm}^{3} \mathrm{~cm}^{-3}$

Figure 10. Relationship (1:1 graphic) between the volumetric soil moisture observed and that estimated with the model proposed by Ledieu et al. (1986). 
Table 3. Analysis of variance for the polynomial models

\begin{tabular}{|c|c|c|c|c|c|c|c|c|c|c|}
\hline \multirow{2}{*}{ Soil } & \multicolumn{3}{|c|}{ Estimate of the parameters } & \multirow{2}{*}{$\begin{array}{c}\text { Linear } \\
\text { coefficient }\end{array}$} & \multirow{2}{*}{$\operatorname{Pr}>\mathbf{F}$} & \multirow{2}{*}{$\mathbf{R}^{2}$} & \multirow{2}{*}{$\mathrm{Sxy}^{(1)}$} & \multicolumn{3}{|c|}{$\operatorname{Pr}>t$} \\
\hline & $\mathbf{K a}$ & $\mathbf{K a}^{2}$ & $\mathbf{K a}^{3}$ & & & & & $\mathbf{K a}$ & $\mathbf{K a}^{2}$ & $\mathbf{K a}^{3}$ \\
\hline All soils & 0.04562 & 0.00174 & 0.000025 & -0.10938 & $<0.0001$ & 0.80 & 0.055 & 0.0009 & 0.0059 & 0.0057 \\
\hline Hapludalf & 0.02595 & 0.00069 & 0.000016 & -0.04019 & $<0.0001$ & 0.96 & 0.020 & 0.4396 & 0.7612 & 0.7797 \\
\hline Hapludox (Passo Fundo-RS) & 0.01041 & 0.00095 & 0.000013 & 0.23645 & 0.0094 & 0.99 & 0.014 & 0.6802 & 0.4127 & 0.4079 \\
\hline Hapludox (Cruz Alta-RS) & 0.02902 & 0.00086 & 0.000012 & 0.01971 & $<0.0001$ & 0.99 & 0.016 & 0.0130 & 0.0632 & 0.0651 \\
\hline Hapludox (Campos Novos-SC) & 0.04231 & 0.00194 & 0.000022 & 0.40283 & 0.0006 & 0.99 & 0.003 & 0.0436 & 0.0334 & 0.0410 \\
\hline
\end{tabular}

(1) Standard error of estimate.

\section{CONCLUSIONS}

1. The models proposed by Topp et al. (1980) and by Ledieu et al. (1986) are not adequate for estimating the volumetric moisture of the four studied subtropical soils.

2. Linear and polynomial models adjusted for the entire set of data of the four soil classes do not have sufficient accuracy for estimating the moisture of the soils studied in a satisfactory way.

3. The specific models for each soil class $\theta=0.40283$ $-0.04231 \mathrm{Ka}+0.00194 \mathrm{Ka}^{2}-0.000022 \mathrm{Ka}^{3}$ (Hapludox from Campos Novos - SC), $\theta=0.01971+0.02902 \mathrm{Ka}-$ $0.00086 \mathrm{Ka}^{2}+0.000012 \mathrm{Ka}^{3}$ (Hapludox from Passo Fundo-RS), $\theta=0.01692-0.00507 \mathrm{Ka}$ (Hapludalf) and $\theta=0.08471+0.01145 \mathrm{Ka}$ (Hapludox from Cruz AltaRS) have greater accuracy and reliability for the estimate of volumetric soil moisture.

\section{LITERATURE CITED}

BAKER, J.M. \& ALLMARAS, R.R. System for automating and multiplexing soil moisture measurement by time domain reflectometry. Soil Sci. Soc. Am. J., 54:1-6, 1990.

BRASIL. Ministério da Agricultura. Levantamento de reconhecimento dos solos do estado do Rio Grande do Sul. Recife, Convênio MA/DRNR, 1973. 431p. (Boletim Técnico)

COELHO, E.F.; VELLAME, L.M.; FILHO, M.A.C. \& LEDO, C.A.S. Desempenho de modelos de calibração de guias de onda acopladas a TDR e a multiplexadores em três tipos de solos. R. Bras. Ci. Solo, 30:23-30, 2006.

COLLARES, G.L.; REINERT, D.J.; REICHERT, J.M. \& KAISER, D.R. Qualidade física do solo na produtividade da cultura do feijoeiro num Argissolo. Pesq. Agropec. Bras., 41:1663-1674, 2006.

COLLARES, G.L.; REINERT, D.J.; REICHERT, J.M. \& KAISER, D.R. Compactação de um Latossolo induzida pelo tráfego de máquinas e sua relação com o crescimento e produtividade de feijão e trigo. R. Bras. Ci. Solo, 32:933942, 2008.
EMPRESA BRASILEIRA DE PESQUISA AGROPECUÁRIA EMBRAPA. Solos do Estado de Santa Catarina. Rio de Janeiro, Embrapa Solos, 2004. 726p.

JACKSON, N.A. \& WALLACE, J.S. Analysis of soil water dynamics in an agroforestry system based on detailed soil water records from time domain reflectometry. Hydrol. Earth System Sci., 3:517-527, 1999.

LEDIEU, J.; RIDDER, P.; CLERCK, P. \& DAUTREBANDE, S. A method for measuring soil water moisture by timedomain reflectometry. J. Hydrol., 88:319-328, 1986.

OTTO, S.R.L. \& ALCAIDE, M. Utilização do método TDRtensiômetro na obtenção da curva de retenção de água no solo. R. Bras. Eng. Agríc. Amb., 25:265-269, 2001.

PEREIRA, S.; FILHO, D.O.; MANTOVANI, E.C.; RAMOS, M.M. \& MARTINS, J.H. Reflectometria no domínio do tempo na determinação do conteúdo de água no solo. R. Bras. Eng. Agríc. Amb., 10:306-314, 2006.

PUMPANEN, J. \& ILVESNIEMI, H. Calibration of time domain reflectometry for forest soil humus layers. Boreal Environ. Res., 10:589-595, 2005.

REICHERT, J.M.; KAISER, D.R.; REINERT, D.J. \& RIQUELME, U.F.B. Variação temporal de propriedades físicas do solo e crescimento radicular de feijoeiro em quatro sistemas de manejo. Pesq. Agropec. Bras., 44:310319, 2009.

SCHNEIDER, P.R.; SCHNEIDER, P.S.P. \& SOUZA, C.A.M. Análise de regressão aplicada à engenharia florestal. Santa Maria, Universidade Federal de Santa Maria, 2009. 294p.

SOUZA, C.F. \& MATSURA, E.E. Avaliação de sondas de TDR multi-haste segmentadas para estimativa da umidade do solo. R. Bras. Eng. Agríc. Amb., 6:63-68, 2002.

SOUZA, C.F. \& MATSURA, E.E. Distribuição da água no solo para o dimensionamento da irrigação por gotejamento. R. Bras. Eng. Agríc. Amb., 8:7-15, 2004.

TEIXEIRA, W.G.; SCHROTH, G.; MARQUES, J.D. \& HUWE, B. Sampling and TDR probe insertion in the determination of the volumetric soil water. R. Bras. Ci. Solo, 27:575-582, 2003.

TOMMASELLI, J.T.G. \& BACCHI, O.O.S. Calibração de um equipamento de TDR para medida da umidade de solos. Pesq. Agropec. Bras., 36:1145-1154, 2001. 
TOPP, G.C.; DAVIS, J.L. \& ANNAN, A.P. Electromagnetic determination of soil water content: Measurement in coaxial transmission lines. Water Res. Res., 16:547-582, 1980 .
TOPP, G.C.; DAVIS, J.L. \& ANNAN, A.P. Electromagnetic determination of soil water content using TDR: I. Applications to wetting fronts and steep gradients. Soil Sci. Soc. Am. J., 46:547-582, 1982. 